\title{
Guillain-Barre syndrome after coronary artery bypass graft surgery: a case report and literature review
}

\author{
Sajid Hameed ${ }^{*}$ (D), Lubna Ashraf Jafri and Dureshahwar Kanwar
}

\begin{abstract}
Background: Guillain-Barre syndrome (GBS) is an acute polyradiculoneuropathy, often preceded by an infection. Rarely, it is preceded by a surgical procedure. Most of the postsurgical GBS cases are reported with the neurosurgical, gastrointestinal, orthopedic, and cardiac procedures. GBS is rarely reported after a coronary artery bypass grafting $(\mathrm{CABG})$. To date, only 12 cases have been reported in the literature. Our case is 13th in number and the first case from Pakistan.

Case presentation: We report a case of a 54-year-old man presented with acute flaccid quadriparesis and areflexia after a CABG procedure. He was subsequently diagnosed with an acute inflammatory demyelinating polyneuropathy (AIDP) variant of GBS and underwent five sessions of plasmapheresis. His weakness improved and could ambulate unassisted on follow-up visits.

Conclusion: GBS is a potentially treatable condition if timely diagnosed and managed. It should be considered in every patient presenting with an acute-onset weakness after surgery.
\end{abstract}

Keywords: Guillain-Barre syndrome, GBS, Coronary artery bypass graft, CABG, Surgery

\section{Background}

Guillain-Barre syndrome (GBS) is an acute-onset monophasic paralytic polyradiculoneuropathy. About two thirds of adult patients experience a precedent event, usually a respiratory or gastrointestinal infection [1]. A precedent surgery has rarely been associated with GBS. Most of the postsurgical GBS cases are reported after neurosurgical, gastrointestinal, and orthopedic procedures [2]. The association of GBS with coronary artery bypass grafting (CABG) is rare. To the best of our knowledge, only 12 cases have been reported in the literature [3-13]. Our case is 13th in number and the first one reported from Pakistan.

\section{Case presentation}

A 54-year-old gentleman presented to the emergency department with quadriparesis with resultant difficulty

\footnotetext{
* Correspondence: drsajidhameed92@gmail.com

Department of Neurology, Aga Khan University, Karachi, Pakistan
}

in ambulation for 2 days. There was no history of fever, trauma, neck pain, backache, bowel or bladder disturbances, vision problems, and preceding respiratory or gastrointestinal illness. Ten days prior to the presentation, he underwent CABG procedure for his triple vessel coronary artery disease without any procedural or post-procedural complications and was discharged home in stable condition. His past medical history is significant for hypertension, dyslipidemia, and ischemic heart disease.

His physical examination revealed a blood pressure of 108/85 mmHg, a heart rate of 78 beats/minute, regular, and a temperature of $36.8^{\circ} \mathrm{C}$. He was awake and oriented. His speech was normal. His cranial nerve examination was unremarkable. Motor examination revealed normal muscle bulk but reduced muscle tone in all four limbs. The muscle strength was assessed to be of Medical Research Council (MRC) grade 3/5 in proximal muscle groups of all four limbs, while the muscle strength in the distal muscles was of MRC grade 2/5. Deep tendon reflexes were absent.

\section{Springer Open}

(๑) The Author(s). 2021 Open Access This article is licensed under a Creative Commons Attribution 4.0 International License, which permits use, sharing, adaptation, distribution and reproduction in any medium or format, as long as you give appropriate credit to the original author(s) and the source, provide a link to the Creative Commons licence, and indicate if changes were made. The images or other third party material in this article are included in the article's Creative Commons licence, unless indicated otherwise in a credit line to the material. If material is not included in the article's Creative Commons licence and your intended use is not permitted by statutory regulation or exceeds the permitted use, you will need to obtain permission directly from the copyright holder. To view a copy of this licence, visit http://creativecommons.org/licenses/by/4.0/. 
Bilateral plantar responses were flexor. Sensory examination was normal. He did not show any signs of respiratory distress.

Anterior spinal cord infarction was our first provisional diagnosis due to an acute presentation of quadriplegia with flaccid limbs, associated with known vascular risk factors, and recent history of cardiovascular intervention. The other differential diagnoses were transverse myelitis, cervical myelopathy, and GBS.

Baseline laboratory investigations were within normal limits (Table 1). Magnetic resonance imaging (MRI) of the spine with contrast (on day 1) did not reveal an acute infarction, spinal cord swelling, or enhancement. Electromyography and nerve conduction studies (EMGNCS) (on day 3) revealed prolonged distal latencies in demyelinating ranges in the motor nerves of both upper and lower extremities, along with slowed conduction velocities and prolonged F-wave. Conduction blocks were seen in bilateral tibial nerves (Table 2). Needle electromyography revealed no motor unit action potentials (MUAPs) in the distal lower extremity muscles up to rectus femoris muscle. There were rapid firing units with normal MUAPs in the rest of the examined muscles. No active axon loss changes were noted. Taken together, these findings were consistent with the diagnosis of an acute inflammatory demyelinating polyneuropathy (AIDP) variant of GBS.

Plasmapheresis (PP) was initiated on day 2 of admission. One session of plasmapheresis was done daily for a total of 5 days with a plasma volume of 1.5 . The decision of PP over intravenous immune globulin (IVIG) treatment was made by the patient's family due to financial constraints. On day 3, patient developed respiratory distress with type-I respiratory failure which was managed in the intensive care unit (ICU) with non-invasive ventilation. He did not require intubation. He was given symptomatic management, prophylaxis for the deep vein thrombosis, hydration, physiotherapy, and rehabilitation. His condition gradually improved and was discharged home (on day 21). He was able to ambulate 10-20 m

Table 1 Baseline investigations

\begin{tabular}{ll}
\hline Investigation & Result \\
\hline Hemoglobin & $13.2 \mathrm{~g} / \mathrm{dl}$ \\
White blood cell count & $6500 / \mathrm{cmm}$ \\
Platelet count & $167,000 / \mathrm{cmm}$ \\
Erythrocyte sedimentation rate & $19 \mathrm{~mm} / 1 \mathrm{st}$ hour \\
Alanine transaminase (ALT) & $45 \mathrm{IU} / \mathrm{l}$ \\
Creatinine & $0.9 \mathrm{mg} / \mathrm{dl}$ \\
Sodium & $145 \mathrm{mEq} / \mathrm{l}$ \\
Potassium & $4.1 \mathrm{mEq} / \mathrm{l}$ \\
Calcium & $8.4 \mathrm{mg} / \mathrm{dl}$ \\
\hline
\end{tabular}

with assistance initially. On the first outpatient followup visit after 2 weeks, his weakness further improved and he was able to ambulate without support.

\section{Discussion}

Guillain-Barre syndrome is postulated to be an immunemediated disorder of the peripheral nerves. It typically manifests as an ascending paralysis but clinical variations do exist. GBS can be life-threatening causing respiratory paralysis, hence, prompt diagnosis and treatment are crucial [1]. This immune dysfunction can be triggered by multiple factors of which surgery is now a known cause, albeit rare [2].

A French nationwide epidemiologic study reported a moderate association of GBS with a recent surgery within the past 60 days (OR: 1.48 [1.22-1.80]). A greater association was reported for orthopedic $(\mathrm{OR}=2.78$ [1.68-4.60]) and gastrointestinal $(\mathrm{OR}=2.36[1.32-4.21])$ procedures [14]. Two other studies reported a 13-times [15] and 6-times [16] increased risk of GBS after surgery, respectively, as compared to the general population. In a review by Zhong et al. ( $n=33)$, postoperative GBS was frequently observed after neurosurgical (33.3\%), cardiac (21\%), gastrointestinal (15\%), transplant (15\%), and orthopedic (12\%) surgeries [2].

The pathophysiology of postoperative GBS is unclear. It is suggested that a transient immunosuppressed state occurs postsurgery that increases the risk of infections, which may induce the process of GBS [17]. A systemic inflammatory response to surgical stress has also been proposed as the presumed etiology. It causes the generation of an immune reaction targeting the myelin sheath in the peripheral nerves [4]. Staff et al. performed nerve biopsies of 23 selected patients with post-surgical neuropathies, out of which 21 (91.3\%) demonstrated inflammation. An elevated protein in cerebrospinal fluid was also reported in 12 out of these 18 patients (67\%) [18].

Although rarely encountered and reported, a patient can present with GBS after CABG surgery. We conducted an online literature search through the MEDL INE (PubMed) and Google Scholar database. We used the following search keywords terms: "GBS" or "Guillain Barre syndrome" and "CABG" or "coronary artery bypass surgery." Our search retrieved a total of 10 case reports and one case series [4] consisting of two case reports, making the total count to 12 cases. Our case is 13th in number. A brief summary of all the cases of GBS following CABG is presented in Table 3. The mean age of presentation is 61.4 years with a range of $50-71$ years. Interestingly, 12 patients out of 13 are male (92.3\%). The onset of symptoms after a CABG surgery ranged from 1 day $[5,12]$ to 12 months [10], with a median duration of 4.5 days. AIDP was the most common GBS variant present in six out of eight patients (75\%). One patient 
Hawed et al. The Egyptian Journal of Neurology, Psychiatry and Neurosurgery

(2021) 57:49

Page 3 of 5

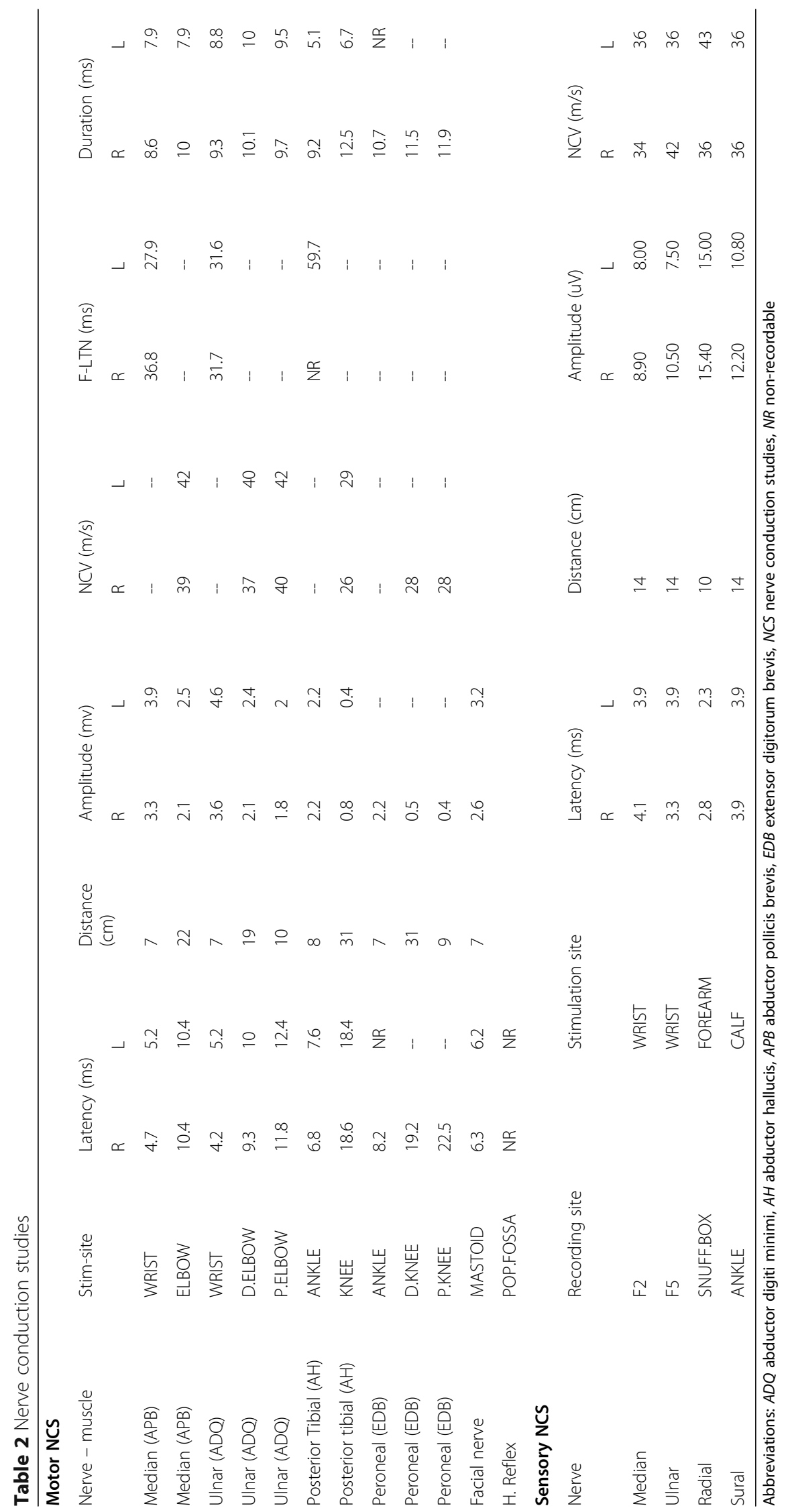


Table 3 GBS cases after cardiac bypass surgery

\begin{tabular}{|c|c|c|c|c|c|c|c|}
\hline S. no. & Author/year & Age (years)/sex & $\begin{array}{l}\text { Onset time } \\
\text { after surgery }\end{array}$ & $\begin{array}{l}\text { Neurological } \\
\text { features }\end{array}$ & GBS variant & Treatment & Outcome \\
\hline 1 & Renlund et al. [3] & $65 \mathrm{M}$ & 9 days & -- & -- & PP & -- \\
\hline 2 & Hogan et al. [4] & $60 \mathrm{M}$ & 15 days & -- & -- & PP & -- \\
\hline 3 & Hogan et al. [4] & $53 \mathrm{M}$ & 15 days & -- & -- & PP & -- \\
\hline 4 & Campbell et al. [5] & $71 \mathrm{M}$ & 1 day & $\begin{array}{l}\text { Quadriparesis, dyspnea, } \\
\text { and dysphagia }\end{array}$ & AIDP & $I V I G$ & Incomplete recovery \\
\hline 5 & Algahtani et al. [6] & $71 \mathrm{~F}$ & 4 days & $\begin{array}{l}\text { Paraparesis, Severe } \\
\text { right leg pain }\end{array}$ & AIDP & PP & $\begin{array}{l}\text { Discharged. Functional } \\
\text { status not known }\end{array}$ \\
\hline 6 & Punith et al. [7] & $65 \mathrm{M}$ & 12 days & $\begin{array}{l}\text { Quadriparesis, } \\
\text { Paraesthesia }\end{array}$ & $\begin{array}{l}\text { Acute axonal } \\
\text { polyneuropathy }\end{array}$ & IVIG & Complete recovery \\
\hline 7 & Cingoz et al. [8] & $67 \mathrm{M}$ & 2 days & $\begin{array}{l}\text { Paraparesis, } \\
\text { Paresthesia }\end{array}$ & --- & PP & Complete recovery \\
\hline 8 & Vettath and Kannan [9] & $70 \mathrm{M}$ & 7 days & Quadriparesis & -- & $I V I G$ & Incomplete recovery \\
\hline 9 & Hekmat (2016) [10] & $52 \mathrm{M}$ & 12 months & $\begin{array}{l}\text { Quadriparesis, } \\
\text { Paresthesia }\end{array}$ & AIDP & IVIG & Incomplete recovery \\
\hline 10 & $\begin{array}{l}\text { Mustafa et al. } \\
\text { (2017) [11] }\end{array}$ & $50 \mathrm{M}$ & 5 days & $\begin{array}{l}\text { Ataxia, ptosis, weakness } \\
\text { and paresthaseia }\end{array}$ & MFS & $\begin{array}{l}\text { Both PP } \\
\text { and IVIG }\end{array}$ & Death \\
\hline 11 & Kumar et al. [12] & $64 \mathrm{M}$ & 1 day & $\begin{array}{l}\text { Dyspnea, } \\
\text { Paraparesis }\end{array}$ & AIDP & IVIG & Complete recovery \\
\hline 12 & Eker et al. [13] & $56 \mathrm{M}$ & 2 days & Paraparesis & AIDP & $I V I G$ & Complete recovery \\
\hline 13 & Present case & $54 \mathrm{M}$ & 10 days & Quadriparesis & AIDP & PP & Incomplete recovery \\
\hline
\end{tabular}

AIDP acute inflammatory demyelinating polyneuropathy, CABG coronary artery bypass grafting, F female, GBS Guillain-Barre syndrome, IVIG intravenous immunoglobulin, $M$ male, MFS Miller Fisher syndrome, $P P$ plasmapharesis

(12.5\%) had Miller-Fischer syndrome (MFS) [11], and one patient (12.5\%) had acute axonal variant [7]. GBS variant in five patients was not mentioned. Standard treatment includes IVIG or PP. Both treatments are equally efficacious and should be started without delay [1]. Of the 13 cases, six patients (46\%) received IVIG and six patients $(46 \%)$ received PP, with one patient $(8 \%)$ received both PP and IVIG [11]. Eight out of 10 (90\%) patients improved after the treatment and were discharged from the hospital, out of which four patients (50\%) achieved complete recovery. Functional status of one patient is unknown [6], while one patient died [11]. Clinical outcome of three patients is unknown $[3,4]$.

\section{Limitations}

In our study, we did not look for cytoalbuminologic dissociation in the cerebrospinal fluid as the diagnosis of GBS was made on clinical grounds along with supportive evidence of the EMG/NCS. Ganglioside antibody testing was also not available. Since most of our data is from scattered case reports, not much information is provided about the patients' comorbidities, surgical complications, and outcome predictors.

\section{Conclusion}

GBS is rarely seen after CABG surgery, but it is a potentially treatable condition if timely diagnosed and managed. IVIG and PP are the main treatment options with equal efficacy. Therefore, GBS should be considered in every patient presenting with an acute-onset weakness after $C A B G$ surgery. Although the diagnosis of GBS is a clinical one, EMG-NCS and CSF examination help in the diagnosis.

\section{Abbreviations \\ ADQ: Abductor digiti minimi; AH: Abductor hallucis; AIDP: Acute inflammatory demyelinating polyneuropathy; APB: Abductor pollicis brevis; CABG: Coronary artery bypass graft; CSF: Cerebrospinal fluid; EMG: Electromyography; EDB: Extensor digitorum brevis; IVIG: Intravenous immune globulin; MFS: Miller Fisher syndrome; MRC: Medical Research Council; MRI: Magnetic resonance imaging; MUAP: Motor unit action potential; NCS: Nerve conduction studies; NR: Non-recordable; \\ PP: Plasmapheresis}

\section{Acknowledgements}

Not applicable.

\section{Authors' contributions}

$\mathrm{SH}$ and $\sqcup$ wrote the manuscript; SH, LJ, and DK contributed significantly to analysis and manuscript preparation; $\mathrm{SH}$ and $\mathrm{L}$ contributed to the conception of the study. The authors have read and approved the manuscript.

\section{Funding}

No funding was obtained for this article.

Availability of data and materials

Not applicable.

\section{Declarations}

Ethics approval and consent to participate Not applicable. 


\section{Consent for publication}

Written informed consent was obtained from the patient for publication of this case report and any accompanying images.

\section{Competing interests}

The authors declare that they have no competing interests.

Received: 11 January 2021 Accepted: 29 March 2021

Published online: 07 April 2021

\section{References}

1. Jacobs BC, Rothbarth PH, Van der Meché FG, Herbrink P, Schmitz PI, De Klerk MA, et al. The spectrum of antecedent infections in Guillain-Barré syndrome: a case-control study. Neurology. 1998;51(4):1110-5. https://doi. org/10.1212/wnl.51.4.1110.

2. Zhong YX, Lu GF, Chen XL, Cao F. Postoperative Guillain-Barre syndrome, a neurologic complication that must not be overlooked: a literature review. World Neurosurg. 2019;128:347-53. https://doi.org/10.1016/j.wneu.2019.04.239.

3. Renlund DG, Hanley DF, Traill TA. Guillain-Barré syndrome following coronary artery bypass artery. Am Heart J. 1987;113(3):844-5. https://doi. org/10.1016/0002-8703(87)90736-8.

4. Hogan JC, Briggs TP, Oldershaw PJ. Guillain-Barre syndrome following cardiopulmonary bypass. Int J Cardiol. 1992;35(3):427-8. https://doi.org/10.1 016/0167-5273(92)90248-2

5. Campbell AJ, McKinlay K, Scott NB. Guillain-Barré syndrome after cardiopulmonary bypass. J Cardiothorac Vasc Anesth. 2009;23(1):82-3. https://doi.org/10.1053/j.jvca.2008.04.019.

6. Algahtani $\mathrm{H}$, Moulin DE, Bolton CF, Abulaban AA. Guillain-Barre syndrome following cardiac surgery. Difficult diagnosis in the intensive care unit. Neurosciences (Riyadh). 2009;14(4):374-8.

7. Punith K, Sudhir U, Rudresh K, Anil KT. Guillain-Barr syndrome following coronary artery bypass surgery. Indian J Med Spec. 2011;2(2):157-9.

8. Cingoz F, Tavlasoglu M, Kurkluoglu M, Sahin MA. Guillain-Barré syndrome after coronary artery bypass surgery. Interact Cardiovasc Thorac Surg. 2012; 15(5):918-9. https://doi.org/10.1093/icvts/ivs367.

9. Vettath M, Kannan AV. Guillaine Barre syndrome after OPCAB Surgery. Surg Sci. 2014;5(12):540-1. https://doi.org/10.4236/ss.2014.512082.

10. Hekmat M, Ghaderi H, Foroughi M, Mirjafari SA. Guillain-Barré syndrome after coronary artery bypass graft surgery: a case report. Acta Med Iran. 2016;54(1):76-8.

11. Mustafa A, Sebnem A, Ufuk C, Hakan K, Levent C. Miller-Fisher syndrome after coronary artery bypass surgery. Cardiovasc J Afr. 2017;28(6):e4-5. https://doi.org/10.5830/CVJA-2017-033.

12. Kumar V, Puri D, Negi S, Rahi SK, Goswami D. Gullain-Barré syndrome following off-pump coronary artery bypass grafting. J Card Surg. 2018;33(9): 539-40. https://doi.org/10.1111/jocs.13780.

13. Eker $E$, Gür $A K$, Şişli E. A rare occurrence of Guillain-Barré syndrome after offpump coronary artery bypass surgery. Eastern J Med. 2019;24(2):249-51. https://doi.org/10.5505/ejm.2019.00821.

14. Rudant J, Dupont A, Mikaeloff Y, Bolgert F, Coste J, Weill A. Surgery and risk of Guillain-Barré syndrome: a French nationwide epidemiologic study. Neurology. 2018;91(13):e1220-7. https://doi.org/10.1212/WNL. 0000000000006246.

15. Gensicke H, Datta AN, Dill P, Schindler C, Fischer D. Increased incidence of Guillain-Barré syndrome after surgery. Eur J Neurol. 2012;19(9):1239-44 https://doi.org/10.1111/j.1468-1331.2012.03730.x.

16. Sipilä JO, Soilu-Hänninen M. The incidence and triggers of adult-onset Guillain- Barré syndrome in southwestern Finland 2004-2013. Eur J Neurol. 2015;22(2):292-8. https://doi.org/10.1111/ene.12565.

17. Wakerley BR, Yuki N. Surgery itself does not trigger Guillain-Barre syndrome. Eur J Neurol. 2013;20(3):e40. https://doi.org/10.1111/ene.12065.

18. Staff NP, Engelstad J, Klein CJ, et al. Post-surgical inflammatory neuropathy. Brain. 2010;133(10):2866-80. https://doi.org/10.1093/brain/awq252.

\section{Publisher's Note}

Springer Nature remains neutral with regard to jurisdictional claims in published maps and institutional affiliations.

\section{Submit your manuscript to a SpringerOpen ${ }^{\circ}$ journal and benefit from:}

- Convenient online submission

- Rigorous peer review

- Open access: articles freely available online

- High visibility within the field

- Retaining the copyright to your article

Submit your next manuscript at $\boldsymbol{\nabla}$ springeropen.com 